加速度計で求めた「健康づくりのための運動基準2006」における身体活動の目標値 （23メッツ・時／週）に相当する歩数

大島 秀武 ${ }^{1,2}$, 引原 有輝 ${ }^{2,3}$, 大河原 一憲 ${ }^{2,4}$, 高田 和子 ${ }^{5}$, 三宅 理江子 ${ }^{2,6}$, 海老根 直之 ${ }^{7}$, 田畑 泉 ${ }^{2,8}$, 田中 茂穂 ${ }^{2}$

\title{
Daily steps corresponding to the reference quantity of physical activity of Exercise and Physical Activity Reference for Health Promotion 2006 (EPAR2006) assessed by accelerometer
}

\author{
Yoshitake Oshima $^{1,2}$, Yuki Hikihara ${ }^{2,3}$, Kazunori Ohkawara ${ }^{2,4}$, Kazuko Ishikawa-Takata ${ }^{5}$, Rieko Miyake ${ }^{2,6}$, \\ Naoyuki Ebine ${ }^{7}$, Izumi Tabata ${ }^{2,8}$ and Shigeho Tanaka ${ }^{2}$ \\ 1 流通科学大学サービス産業学部，７651-2188 兵庫県神戸市西区学園西町3-1 (Faculty of Service Industries, University of \\ Marketing and Distribution Sciences, 3-1 Gakuen-Nishimachi, Nishi-ku, Kobe 651-2188, Japan) \\ 2 独立行政法人国立健康 - 栄養研究所健康增進研究部, ₹ 162-8636 東京都新宿区戸山1-23-1 (Department of Health Pro- \\ motion and Exercise, National Institute of Health and Nutrition, 1-23-1 Toyama, Shinjuku-ku, Tokyo 162-8636, Japan) \\ 3 千葉工業大学工学部体育教室, ７275-0023 千葉県習志野市芝園2-1-1 (Faculty of Engineering, Chiba Institute of Tech- \\ nology, 2-1-1 Shibazono, Narashino, Chiba 275-0023, Japan) \\ 4 電気通信大学情報理工学部, = 182-8585 東京都調布市調布ヶ丘1-5-1 (Faculty of Informatics and Engineering, Univer- \\ sity of Electro-Communications, 1-5-1 Chofugaoka, Chofu, Tokyo 182-8585, Japan) \\ 5 独立行政法人国立健康・栄養研究所栄養教育研究部, T162-8636 東京都新宿区戸山1-23-1 (Department of Nutritional \\ Education, National Institute of Health and Nutrition, 1-23-1 Toyama, Shinjuku-ku, Tokyo 162-8636, Japan) \\ ${ }^{6}$ お茶の水女子大学大学院人間文化創成科学研究科， = 112-8610 東京都文京区大塚2-1-1 (Graduate School of Humanities \\ and Sciences, Ochanomizu University, 2-1-1 Ohtsuka, Bunkyo-ku, Tokyo 112-8610, Japan) \\ ${ }^{7}$ 同志社大学スポーツ健康科学部, = 610-0394 京都府京田辺市多々羅都谷1-3 (Faculty of Health and Sports Science, \\ Doshisha University, 1-3 Tatara-Miyakodani, Kyo-Tanabe, Kyoto, 610-0394, Japan) \\ 8 立命館大学スポーツ健康科学部，７525-8577 滋賀県草津市野路東1-1-1 (Faculty of Health and Sports Science, Ritsumei- \\ kan University, 1-1-1 Noji-Higashi, Kusatsu, Shiga 525-8577, Japan)
}

\section{Received: August 29, 2011 / Accepted: January 16, 2012}

\begin{abstract}
The purpose of this study was to determine daily steps corresponding to the reference value for the quantity of Physical Activity and Exercise for Health Promotion 2006 (23 METs $\cdot \mathrm{h} /$ wk) considering non-locomotive activities. Two hundred and thirty one men and 224 women wore a tri-axial accelerometer for two weeks. We analyzed the data in each age group (young (less than 40 years), middle-aged (40 to 59 years), and elderly (60 years or more) groups), also. There were significant relationships between daily steps and locomotive activity $(r=0.762$ to $0.820, \mathrm{p}<$ $0.001)$ and total (locomotive and non-locomotive) physical activity $(\mathrm{r}=0.706$ to $0.824, \mathrm{p}<0.001)$ with intensity of 3 METs or more in all groups. The daily steps corresponding to $23 \mathrm{METs} \cdot \mathrm{h} / \mathrm{wk}$, calculated using regression lines between the daily steps and total physical activities with intensity of 3 METs or more in men and women were 6,534 steps/d and 6,119 steps/d. On the other hand, the daily steps corresponding to $23 \mathrm{METs} \cdot \mathrm{h} / \mathrm{wk}$, calculated using regression lines between the daily steps and locomotive activities with intensity of 3 METs or more in men and women were 7,888 steps/d and 8,584 steps/d. These results suggest that non-locomotive activity should also be taken into consideration in the case of assessment of a daily physical activity.
\end{abstract}

Jpn J Phys Fitness Sports Med, 61(2): 193-199 (2012)

Keywords : daily steps, physical activity, Exercise and Physical Activity Reference for Health Promotion 2006, accelerometer, non-locomotive activity

\section{緒言}

日常生活が活動的な者において，生活習慣病の発症リ スクが低いことが報告されている1)。適度な活動量を維 持するためには, 現状の身体活動量を知り, 個人のライ フスタイルに応じて日常生活の中に運動を取り入れてい
くことが必要である.

これまで，身体活動を定量的に評価する方法として， 質問紙法, 歩数計法, 加速度計法, 心拍数法, 二重標識 水法（DLW法）などが用いられてきた ${ }^{2)}$. 中でも歩数計 は，その簡便性と指標のわかりやすさから，我が国の国 民健康・栄養調査 ${ }^{3}$ をはじめ, 多くの研究で用いられて 
いる. 日本から発信された「1日 1 万歩」という目標值 についても，国内外を問わず，その妥当性に関して議論 がなされており ，わが国に打いても，1993年に出され た「健康づくりのための運動指針」では 1 日の合計歩数 は 1 万歩が目標とされた ${ }^{5)}$ 。さらに平成 12 年から取り組

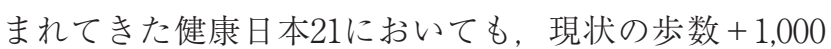
歩が 1 日の身体活動の目標值として揭げられている6 ${ }^{6}$.

一方，2006年に厚生労働省が策定した「健康づくりの ための運動基準2006～身体活動・運動・体力〜（以下， 運動基準2006)」77では, 生活習慣病予防の観点から, 歩 行に限らず，仕事や家事などの日常生活活動を含む中等 度以上の活動強度の必要性を強調している。 また, 健康 の維持・増進に必要な身体活動・運動量として, 強度が 3 メッッ以上の身体活動を 23 メッッ・時／週以上，その うち運動を 4 メッツ・時/週以上実践することが推奨さ れている. 23 メッッ・時/週の身体活動量とは，3メッ ツ以上の強度の身体活動を 1 日あたり約 60 分行うことに 相当し, 歩行中心の活動で考えると, 約6,000歩（10分 あたり1,000歩で60分）に，低強度で意識されない歩数 約2,000〜4,000歩を加えた 1 日あたり8,000〜10,000歩が 目安になると示されている77. しかしながら，これはあ くまでも試算したものであり，23メッツ・時／週と 1 日 あたり8,000 10,000歩が日常生活環境下で実際に一致す るかどうかは検討が必要である。

日常生活の中で，歩行は代表的な身体活動の一つであ るが，歩行以外にも掃除機かけや洗濯などの家事活動の ように上半身も動かす複雑な活動を行っている，運動基 準2006では，体力の維持・向上を目的として計画的・意 図的に実施する運動だけではなく，これらの家事活動な どをも含めた身体活動の総量についての基準值が設けら れている。そそのため，日常生活に扔ける身体活動量を， より正しく捉えた上で23メッッ・時／週がどの程度の歩 数に相当するのかを明らかにすることが必要である。そ こで本研究では, 歩行以外の生活活動も評価可能な 3 次 元加速度計を用い, 性 ·年齢階級別に加えて, 身体活動
を強度が 3 メッツ以上の歩行活動のみに限定した場合と

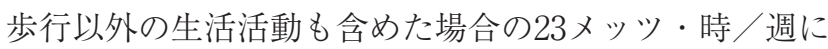
相当する歩数について明らかにすることを目的とした．

\section{方法}

対象 主に京都市近郊に在住し，事前のアンケート調査 により，健康診断等で医師から内科的または整形外科的 な疾患によって運動制限されていないことが確認された 男性231名，女性224名の計455名を対象とし，若年者群 (40歳未満の男性84名, 女性81名), 中年者群 (40歳以上 60歳未満の男性100名, 女性93名), 高齢者群（60歳以上 の男性47名，女性50名）の3 群に分けて検討を行った (Table 1)。主な職種と人数は, 男性で自営業25名, 事 務職106名，技能職21名，営業職41名，無職または主夫 38 名であり，女性で自営業12名，事務職61名，技能職31 名，営業職38名，無職または主婦82名であった。

歩数および身体活動量の測定 歩数と活動量の測定に は，データメモリ機能を有するオムロンヘルスケア社製 の活動量計Active Style Pro（HJA-350IT）を用いた。 本装置は，幅 $74 \times$ 高さ $46 \times$ 奥行き $34 \mathrm{~mm}$ ，質量が $60 \mathrm{~g}$ であ り, 腰部にクリップで装着して計測する仕様となってい る。 3 軸の加速度デー夕をもとに歩数と活動量をそれぞ れ独自のアルゴリズムで演算するが，歩数については， 加速度波形の振幅の大きさが予め決められた間值以上に なり，かつその動きが 2 秒間続いた場合に歩行と認識さ れ,カウントされる ${ }^{8)}$. また, 活動量の演算にあたっては, 活動強度にかかわらず，加速度信号の重力加速度成分の 変化から，活動時に上半身の傾斜変化がみられない歩 · 走行などの歩行活動と, 活動時に上半身の傾斜変化を伴 う荷物運びや掃除機かけなどの生活活動に分類され，そ れぞれの身体活動時における合成加速度と活動強度の関 係式を用いて歩行活動強度㧍よび歩行以外の生活活動強 度が計測されるという特徵を有している9,10)

活動量計は 2 週間装着してもらい，1 日の歩数抄よび

Table 1. Physical characteristics in different age groups.

\begin{tabular}{ccccccc}
\hline & Group & $\mathrm{N}$ & $\begin{array}{c}\text { Age } \\
(\mathrm{yr})\end{array}$ & $\begin{array}{c}\text { Height } \\
(\mathrm{cm})\end{array}$ & $\begin{array}{c}\text { Weight } \\
(\mathrm{kg})\end{array}$ & $\begin{array}{c}\mathrm{BMI} \\
\left(\mathrm{kg} / \mathrm{m}^{2}\right)\end{array}$ \\
\hline \multirow{3}{*}{ Men } & Young & 84 & $31.1 \pm 5.5$ & $173.1 \pm 7.2$ & $74.2 \pm 16.3$ & $24.7 \pm 4.9$ \\
& Middle-age & 100 & $47.5 \pm 5.4 *$ & $169.9 \pm 6.3 *$ & $72.0 \pm 11.8$ & $24.9 \pm 3.6$ \\
& Elderly & 47 & $66.3 \pm 4.2 * \dagger$ & $166.1 \pm 5.9 * \dagger$ & $68.0 \pm 9.7 *$ & $24.7 \pm 3.3$ \\
\hline \multirow{2}{*}{ Women } & Young & 81 & $32.3 \pm 5.1$ & $159.7 \pm 5.5$ & $63.7 \pm 15.6$ & $24.9 \pm 5.8$ \\
& Middle-age & 93 & $48.7 \pm 5.8 *$ & $157.8 \pm 5.0 *$ & $63.8 \pm 11.3$ & $25.6 \pm 4.1$ \\
& Elderly & 50 & $65.0 \pm 4.1 * \dagger$ & $153.2 \pm 5.1 * \dagger$ & $57.5 \pm 8.2 * \dagger$ & $24.5 \pm 3.5$ \\
\hline
\end{tabular}

Values are mean $\pm \mathrm{SD}$.

$\mathrm{BMI}$ indicates body mass index.

* : Significant difference from Young group $(\mathrm{p}<0.05)$

$\dagger$ : Significant difference from Middle-age group $(\mathrm{p}<0.05)$ 
MVPA (moderate-to-vigorous physical activity) の指 標として, 強度が 3 メッッ以上の歩行活動量 (locomotive MVPA）と生活活動量（non-locomotive MVPA), その 合計值（total MVPA）を算出した。対象者には, 睡眠 および活動量計が水に浸かる活動（入浴や水泳など）以 外の全ての時間に活動量計を装着するように指示した。 2 週間の装着後に活動量計を回収し, 専用ソフトを用い て解析を行った。 日々の活動量のデータは, 1 分ごとに 加速度信号の有無を確認し，1日あたり合計10時間以上 の加速度信号が検出された日を装着日とし, 平日 2 日, 休日 1 日の計 3 日以上の装着日があったデータを解析に 採用した。

倫理面への配慮 本研究は, 独立行政法人国立健康 - 栄 養研究所「研究倫理審査委員会 - 疫学研究部会」の承認 を得て実施した。測定にあたって, 対象者に測定の目的, 利益, 不利益, 危険性, デー夕の管理や公表について説 明を行い, 書面にて同意を得た。データは慎重に管理し, 外部に流出することがないようにした。測定に伴う危険 性はない.

統計処理 解析結果は, 平均值士標準偏差で示した. 男 女間の差の検定には, 対応のない $\mathrm{t}$ 検定を用いて解析 した。年齢階級別の 3 群間の平均值の比較には, 一元 配置分散分析法を用い, その後の多重比較にはTukeyの post-hoc検定を用いた。 また, 歩数と活動量との関連性 は, ピアソンの相関係数によって検討し, 単回帰により 回帰直線を求めた。解析にはSPSS15.0Jを使用し, 統計 学的有意水準はすべて $5 \%$ 未満とした。

\section{結果}

対象者の身体特性をTable 1 に示した。 男女ともBMI を除くすべての指標において，年齢階級間で有意な差
が認められた（ $\mathrm{p}=0.04 〜 \mathrm{p}<0.001 ） .1$ 日あたりの歩 数は男性が平均 $7,293 \pm 2,815$ 歩 /日, 女性が平均 $6,607 \pm$ 2,315歩／日であり，女性に比較して男性で有意に高值 を示した $(\mathrm{p}=0.005)$. 男女別年齢階級別にみたところ, 男女ともに年齢階級別の 3 群間で有意な差は認められな かった (Table 2).

強度が 3 メッツ以上の生活活動は, 男性が平均 $8.1 \pm 7.2$ メッッ・時／週，女性が平均 $12.4 \pm 8.5$ メッツ・時／週で あり，男性に比較して女性で有意に高值を示した（ $\mathrm{p}<$ 0.001). 年齢階級別での検討では，女性においてのみ 3 群間で有意な差が認められ，若年者群で他の群よりも低 值を示した。また, 強度が 3 メッツ以上の歩行活動は, 男性が平均 $19.9 \pm 11.6$ メッツ・時／週，女性が平均 14.0 \pm 7.9 メッッ・時／週であり，女性に比較して男性で有 意に高值を示した（ $\mathrm{p}<0.001 ）$ ，年齢階級別での検討で は，男女ともに 3 群間で有意な差が認められ，男性では 高齢者群で他の群よりも低值を示し，女性では若年者群 で他の群よりも高值を示した。ささに，強度が 3 メッッ 以上の生活活動と歩行活動を合計した総活動量は，男性 が平均 $28.0 \pm 14.2$ メッツ・時／週，女性が平均 $26.4 \pm 11.7$ メッッ・時／週であり，男女間で有意な差が認められな かった，年齢階級別での検討では，男性においてのみ 3 群間で有意な差が認められ，高齢者群で他の群よりも低 值を示した。

また, 強度が 3 メッツ以上の総活動量に占める歩行 活動の割合は，男性が平均 $70.2 \pm 19.0 \%$, 女性が53.6土 19.0\%であり，女性に比較して男性で有意に高值を示し た $(\mathrm{p}<0.001)$. 年齢階級別での検討では, 男女ともに 3 群間で有意な差が認められ，男性では高齢者群で他の 群よりも低值を示し，女性では若年者群で他の群よりも 高值を示した。

1 日あたりの歩数と強度が 3 メッッ以上の週あたりの 総活動量との間には，男女ともに有意な相関関係が認め

Table 2. Physical activity parameter by accelerometer in different age groups.

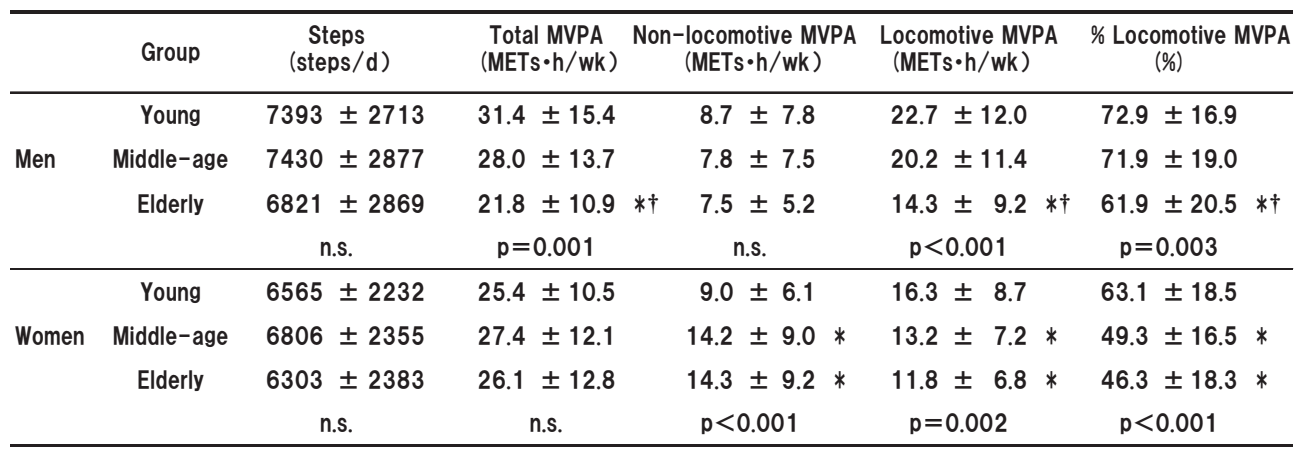

Values are mean $\pm \mathrm{SD}$.

MVPA indicates moderate to vigorous physical activity with intensity 3 METs or more

Locomotive MVPA indicates MVPA during locomotive activity.

Non-locomotive MVPA indicates MVPA during non-locomotive activity.

* : Significant difference from Young group $(p<0.05)$.

$\dagger$ : Significant difference from Middle-age group $(\mathrm{p}<0.05)$. 
られた（男性： $\mathrm{r}=0.770, \mathrm{p}<0.001$ ，女性： $\mathrm{r}=0.726$, $\mathrm{p}<0.001)$ ．また，男女ともに，1日あたりの歩数と強 度が 3 メッッ以上の週あたりの歩行活動との間には強い 相関が（男性： $\mathrm{r}=0.795, p<0.001$, 女性 : $\mathrm{r}=0.747$, $\mathrm{p}<0.001$ ), 生活活動との間には弱い相関（男性： $\mathrm{r}=$ $0.240, \mathrm{p}<0.001$, 女性： $\mathrm{r}=0.311, \mathrm{p}<0.001 ）$ が認め られた。年齢階級別での検討では，すべての群において 1 日あたりの歩数と強度が 3 メッッ以上の週あたりの歩 行活動（ $r=0.762 \sim 0.820, \quad \mathrm{p}<0.001)$ ，㧍よび総活動 量（ $\mathrm{r}=0.706 \sim 0.824 ， \mathrm{p}<0.001 ）$ との間に有意な相関 関係が認められた（Fig.1，2）。一方，1日あたりの歩 数と強度が 3 メッッ以上の週あたりの生活活動との関 係については，男性の若年者群 $(\mathrm{r}=0.272, \mathrm{p}=0.012)$
および中年者群（ $\mathrm{r}=0.264, \mathrm{p}=0.008)$, 女性の中年者 群（ $\mathrm{r}=0.361 ， \mathrm{p}<0.001 ）$ および高齢者群（ $\mathrm{r}=0.422$, $\mathrm{p}=0.002 ） に$ においてのみ有意な相関関係が認められた.

強度が 3 メッツ以上の週あたりの総活動量と歩数の関 係によると，健康の維持・増進に必要な身体活動推奨量 である23メッッ・時／週に相当する歩数は，男性で6,534 歩／日，女性で6,119歩／日であった。一方，歩行活動 と判定された活動のみに限定した場合に得られる23メッ ツ・時／週に相当する歩数は，男性で7,888歩／日，女 性で8,584歩／日であった。

男女別・年齢階級別でみると，23メッツ・時／週に相 当する歩数は，歩行活動と歩数との関係から算出した場 合に比へ，総活動量と歩数の関係から算出した場合にお

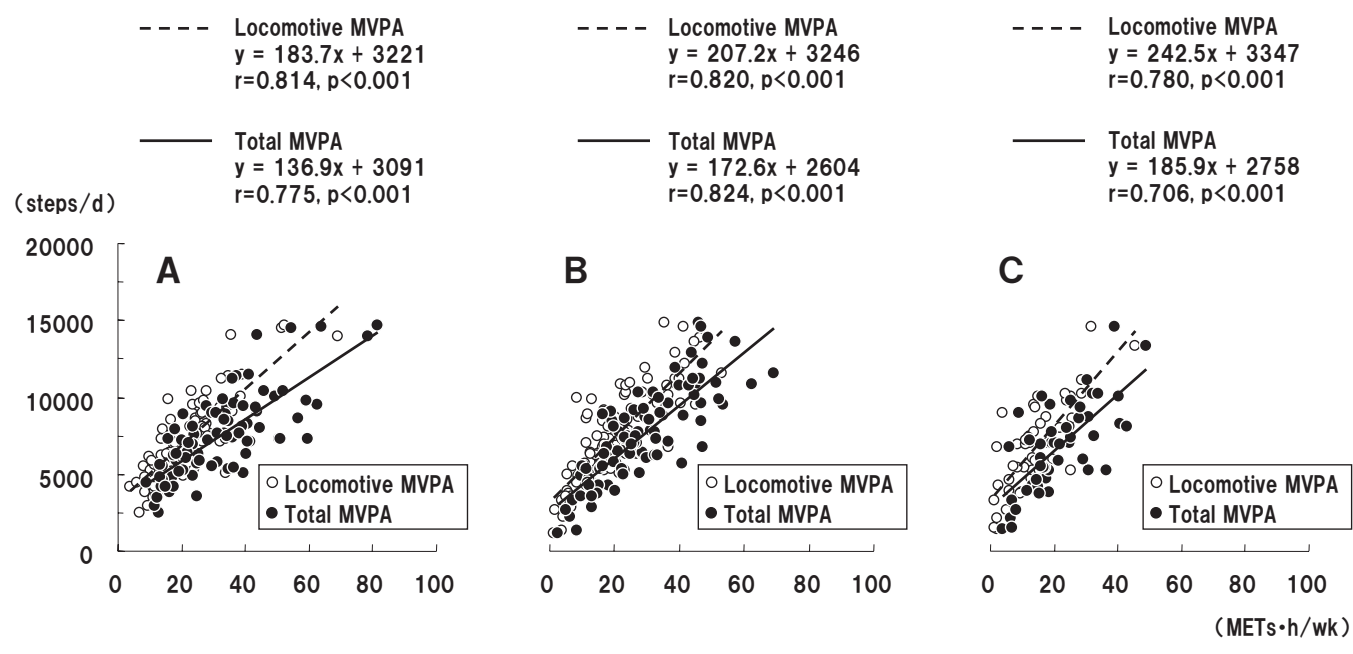

Fig 1. Relationships between daily steps and weekly MVPA in men.

MVPA indicates moderate to vigorous physical activity with intensity of 3 METs or more Locomotive MVPA indicates MVPA during locomotive activity.

A: Young group, B: Middle-age group, C: Elderly group.

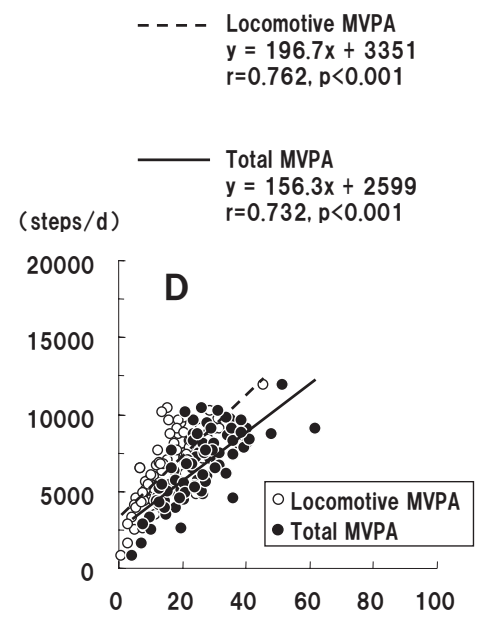

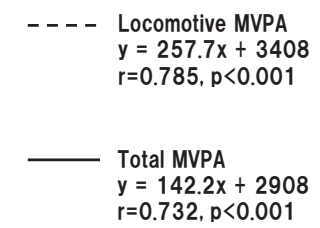

$E$

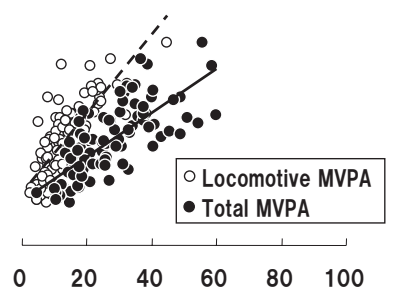

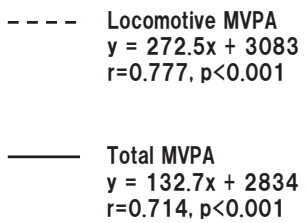

$\mathbf{F}$

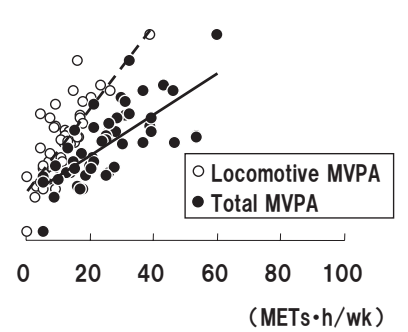

Fig 2. Relationships between daily steps and weekly MVPA in women.

MVPA indicates moderate to vigorous physical activity with intensity of 3 METs or more. Locomotive MVPA indicates MVPA during locomotive activity.

D: Young group, E: Middle-age group, F: Elderly group. 
いて, 男性では若年者群で1,206歩, 中年者群で1,437歩, 高齢者群で1,889歩，それぞれ少なく，女性では若年者 群で1,680歩, 中年者群で3,156歩, 高齢者群で3,463歩, それぞれ少なくなり, 男女ともに加龄に伴って歩数の差 が大きくなる傾向が認められた.

\section{考察}

本研究は, 3 メッツ以上の身体活動量と歩数との関係 について，歩行と歩行以外の身体活動を分離した計測が 可能な加速度計を用いて得られた知見に基づいていると いう点に特徵がある。 日常生活において, 歩行以外の生 活活動は，1日の身体活動が日本人の標準的なPAL（身 体活動レベル）である1.75程度の生活では，2４４時間 程度の普通歩行に相当する身体活動量にもなることが報 告されている11)。こういった生活活動を含めた身体活動 量の推定に対して, 加速度計が用いられているが, 国内 外において, 1 次元 $\cdot 3$ 次元加速度計のいずれについて も, 歩行時に得られた加速度と活動強度の関係に基づく 推定式が適用されることが多く, 歩行以外の生活活動を 過小評価する傾向にあった ${ }^{12,13)}$. そのため, これまでに も加速度センサを用いて, 歩行以外の生活活動を精度よ く計測しようとする試みがなされている ${ }^{14,15)}$ 。我々も独 自のアプローチにより，3 次元加速度の重力加速度成分 の情報に基づいて上半身の傾斜の変化をとらえ, 歩行系 活動に加えて日常生活活動も精度よく評価できるアルゴ リズムを開発した9,10)。このアルゴリズムは, 活動夕イ プによって加速度に対する重力加速度の寄与が異なるこ とを利用し, 歩行活動による身体活動と歩行以外の生活 活動による身体活動に分類するという特徵を有してい る9)。また，活動量計で得られた計測值の妥当性につい ては, ダグラスバッグ法を基準として, 歩行や家事など の12種類の動作において，それぞれ平均 $\pm 6 \%$ 以内の誤 差で活動強度を推定できる10)。さらに, ゆっくりとした 歩行でも, 歩数や強度を他機種と比べても正確に評価で きることも確認されている16). この活動量計を用いて計 測した 1 日の歩数と強度が 3 メッツ以上の週あたりの総 活動量との関係式から $23 \times ッ ッ ・$ 時 / 週に相当する歩数 を算出したところ, 男性で6,534歩／日，女性で6,119歩 ／日となり，歩行中心の活動で考えた場合の目安として

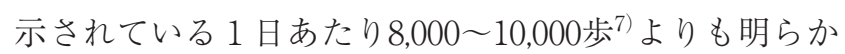
に低い值が得られた。また，年齢階級別にみても23メッ ツ・時／週に相当する歩数には大きな差はなかった。こ のことから, 性・年代にかかわらず, 生活活動も身体活 動量の増加に貢献しており, 歩行活動を高く維持するこ とだけが必ずしも運動基準を満たす条件ではないことが 示唆された。

運動基準2006によれば,「3メッッ」以上の身体活動 には, 歩行以外に屋内の掃除, 掃除機かけ, 風吕掃除
といった家事活動なども含まれている7).こういった家 事活動は上半身の動作が中心となるため, 歩数には反 映されにくい. 先行研究において, 3 メッッ強度の 1 分間あたりの歩数, 即ち歩行率は, 歩行活動で100歩／ 分前後17)であるのに対して，家事活動では，60歩／分程 度 ${ }^{18)}$, あるいは, それよりも少ない13)ことが報告されて いる。このように活動の内容によって活動強度と歩行率 の関係性は異なるため, 少ない歩数であっても, 活発な 生活活動によって身体活動量を増すことが可能であると 考えられる。

本研究において，3メッツ以上の活動が歩行活動のみ であると想定し，1日の歩数と強度が 3 メッッ以上の週 あたりの歩行活動との関係から，23メッツ・時／週に相 当する歩数を算出したところ, 男性は7,888歩 $/$ 日, 女 性は8,584歩／日であった。これは，歩行中心の活動の 場合には，1 日あたり8,000～10,000歩を目安とすること が妥当であったことを示唆している。また，23メッツ・ 時／週に相当するかどうかにかかわらず，1日の歩数 を8,000〜10,000歩に維持することが生活習慣病の予防に 効果がある可能性がいくつかの論文より示唆されてい る ${ }^{19-21)}$ ため, 望ましい身体活動量としてのひとつの目標 值にすることは有用かつ実践的であると思われる。その 一方で, 本研究での運動基準の目標值に相当する歩数は, 現在, 国民健康・栄養調査で得られている平均值に近い 值であった，運動基準2006では，週あたり23メッッ・時 ／週が目標值として設定されている。しかしながら，こ の目標值は主に欧米人を対象として質問紙調査で評価し た身体活動量に基づく疫学研究結果から出されたもので ある7). また，目標值の設定の際にレビューされた論文 で用いられた質問紙を考えると, 総身体活動量というよ りは, 余暇時間の活動量を中心に扱っており，仕事中の 活動や通勤, 家事などについては部分的にしか考慮され ていない7)。そのため, 今後, 身体活動量の目標值の妥 当性について, 加速度計などを用いて検証した上で歩数 との関連性を調査する必要があるものと思われる。

年齢階級別に見ると, 男女ともに高齢者群で歩行活動 による23メッツ・時／週に相当する歩数が高值を示した。 高齢者では筋力低下に伴う歩幅の減少によって歩行速度 が低下することが報告されている22)，歩幅が減少した状 態で 3 メッツ強度の歩行を行うためには, 歩行率を高め ることが必要となり, 特に高齢者では負担が大きくなる。 このことは, 本研究において強度が 3 メッッ以上の週あ たりの歩行活動が男女ともに若年者群に比べて高齢者群 で有意に低值であったことからも明らかであり，特に歩 数や歩行活動を中心とした身体活動による目標值を設定 する場合には，性・年齢などを考慮する必要があると思 われる。

先行研究では, 成人男女 92 名を対象として, 加速度セ 
ンサを用いて歩数および強度が 3 メッツ以上の活動量を 測定することで 23 メッ・時／週に相当する歩数を算出 し，10,652歩／日と本研究の結果に比較して高い值が報 告されている23)。 また, Tudor-Lockeら ${ }^{24)}$ は，6つの研 究のレビュー結果に基づき，1日あたり30分の中等度 から高強度の身体活動（Moderate to vigorous physical activity: MVPA）は，7,000～8,000歩／日に相当すると 報告している. 先行研究に扔いて身体活動量のガイドラ インに相当する歩数が, 本研究の結果よりも高い傾向と なっている要因の一つとして, 先行研究で用いられた加 速度計による活動強度の算出式が，歩行時に得られた加 速度と活動強度の関係式に基づいて作成されたもの ${ }^{25}$ で あることがあげられる。加速度と活動強度の関係性は, 歩行と生活活動とで異なるため, 歩行時に得られた加速 度と活動強度の関係式を用いると, 歩行以外の生活活動 を過小評価する傾向にあることが報告されている ${ }^{12,13)}$. そのため, 強度が 3 メッッ以上の歩行活動と歩行以外の 生活活動を合わせた総活動量も過小評価してしまうこと が推測され，それによって23メッッ・時／週に相当する 歩数も大きな值となっている可能性が考えられた.

歩数と強度が 3 メッツ以上の歩行活動または総活動量 との関係式から算出した23メッッ・時／週に相当する歩 数の差についてみたところ, 男女ともに大きな差が認め られ，その差は女性㧍よび高齢者群で顕著であった。ま た，強度が 3 メッッ以上の総活動量に対する歩行活動の 割合についても同様に男性よりも女性で小さく, 男女と もに高齢者で低值を示しており，ライフスタイルの違い が，これらの結果に影響していることが示唆された。家 事などの生活活動では強度の高い活動は少なく，1回の 継続時間も短い場合がほとんどである。一回の身体活動 の継続時間について, アメリカスポーツ医学会とアメリ カ心蔵学会が作成した身体活動ガイドラインでは, 一回 当たりの運動継続時間が10分間の場合と30分間の場合と で効果に差がないという報告に基づいて，10分以上の継 続が明記されているものの ${ }^{26)}$ ，わが国の運動基準2006で は規定されていない，そのため，本研究のように，1分 単位で活動強度を評価する方法は，運動基準2006に対応 していると考えられる，先行研究では，日常生活での細 切れの身体活動の蓄積と，30分以上の連続的な身体活動 を比較し，同程度の運動量の実施では $\dot{\mathrm{V}} \mathrm{O}_{2} \max$ の改善効 果に差がなかったこと ${ }^{27)}$ や， 3 分間 $\times 10$ 回の運動は，食 後高脂血症や血圧の改善に対して 30 分 $\times 1$ 回の運動と同 等の効果であったこと每新報告されている。また，運動 に対するコンプライアンスについても 1 回にまとめて実 施するよりも，複数回に分けて実施するほうが高いこと が報告されている ${ }^{29)}$. そのため, ウォーキングを中心と した身体活動のみでなく，日常生活での家事活動の増加 などによって活動量を増やすことも有効かもしれない，
今後, 家事活動などの歩行以外の活動によってどの程度, 身体活動量を増加させることが可能か，ささらに増やすこ とによる身体機能に対する効果はどうか，といったこと を検討する必要があると思われる。

本研究の限界として, 対象者が都市部の一部地域に限 定されている点が挙げられる，また，事前のスクリーニ ングによって，医師から運動制限されていない者を抽出 したため，特に高齢群においては一般集団よりも健康集 団であり，相対的に身体活動量が多かった可能性が考え られる。そそのため，幅広い地域の集団に対しても同様の 結果が当てはまるとは限らない，今後，調査地域を拡大 し，対象者をランダムに抽出した上でのさらなる検討が 必要であると思われる。最後に，本研究で用いた活動量 計の身体活動量は, 歩行と歩行以外の身体活動量を加味 したアルゴリズムで演算されたものである。そのため, 本結果を他の歩行を前提にエネルギー消費量を算出した 加速度計で得られた結果にあてはめることはできない。 用いる歩数計および活動量計の機種によって計測アルゴ リズムが異なるため, 結果も異なる可能性があることに 留意する必要がある。

\section{まとめ}

歩行以外の生活活動も評価可能な 3 次元加速度計を用 い, 健康の維持・増進に必要な身体活動量として推奨さ れている23メッッ・時／週に相当する歩数を検討した 結果, 男性で6,534歩／日，女性で6,119歩／日であった。 一方, 身体活動量を強度が 3 メッッ以上の歩行活動のみ に限定して考えた場合，23メッッ・時／週に相当する 歩数は男性で7,888歩／日，女性で8,584歩／日であった。 このことから, 歩行以外の生活活動も身体活動量の増加 に貢献して扮り，身体活動量を評価する際に考慮すべき ことが示唆された。

\section{参 考 文 献}

1) US Department of Health \& Human Services. Physical Activity Guidelines Advisory Committee Report 2008, 2008. http://www.health.gov/PAGuidelines/Report/.

2) Montoye HJ, Kemper, HCG, Saris WHM, Richard AW. Measuring physical activity and energy expenditure, Human Kinetics, Champaign, IL, 1996.

3) Inoue S, Ohya Y, Tudor-Locke C, Tanaka S, Yoshiike N, Shimomitsu T. Time Trends for Step-Determined Physical Activity among Japanese Adults. Med Sci Sports Exerc, 43: 1913-1919, 2011.

4) Tudor-Locke C, and Bassett DR Jr. How many steps/ day are enough? Preliminary pedometer indices for public health. Sports Med, 34: 1-8, 2004.

5）進藤宗洋，吉田規和：日本の厚生省の“健康づくりのた めの運動所要量”, pp202-208. 日本臨床増刊号「身体 活動と生活習慣病」，日本臨床社，2000．

6）健康日本21企画検討会, 計画策定検討委員会報告書： 
健康日本21（21世紀における国民健康づくり運動につ いて)，健康体力づくり事業財団，東京，2000.

7）厚生労働省運動所要量 - 運動指針の策定検討会. 健康 づくりのための運動基準2006-身体活動·運動·体力 - . 2006.

8）大島秀武. 身体活動量をはかる最新技術. 体育の科学, $61: 108-112,2011$.

9) Oshima Y, Kawaguchi K, Tanaka S, Ohkawara K, Hikihara Y, Ishikawa-Takata K, and Tabata I. Classifying household and locomotive activities using a triaxial accelerometer. Gait Posture, 31: 370-374, 2010.

10) Ohkawara K, Oshima $Y$, Hikihara $Y$, Ishikawa-Takata K, Tabata I, Tanaka S. Real-time estimation of daily physical activity intensity by triaxial accelerometer and a gravity-removal classification algorithm. $\mathrm{Br} J$ Nutr, 105: 1681-1691, 2011.

11) Ohkawara K, Ishikawa-Takata K, Park JH, Tabata I, Tanaka S. How much locomotive activity is needed for an active physical activity level: analysis of total step counts. BMC Res Notes, 4: 512, 2011. [Epub ahead of print]

12) Matthews CE. Calibration of accelerometer output for adults. Med Sci Sports Exerc, 37: S512-S522, 2005.

13) Hikihara Y, Tanaka S, Ohkawara K, Ishikawa-Takata K, Tabata I. Validation and comparison of three accelerometers for measuring physical activity intensity during nonlocomotive activities and locomotive movements. $J$ Phys Act Health, in press.

14) Crouter SE, Clowers KG, and Bassett DR Jr. A novel method for using accelerometer data to predict energy expenditure. J Appl Physiol, 100: 1324-1331, 2006.

15) Staudenmayer J, Pober D, Crouter S, Bassett D, and Freedson P. An artificial neural network to estimate physical activity energy expenditure and identify physical activity type from an accelerometer. J Appl Physiol, 107: 1300-1307, 2009.

16) Park J, Ishikawa-Takata K, Tanaka S, Mekata Y, Tabata I. Effects of walking speed and step frequency on estimation of physical activity using accelerometers. $J$ Physiol Anthropol, 30: 119-127, 2011.

17）綾部誠也, 熊原秀晃, 青木純一郎, 内藤久士, 形本静 夫, 田中宏暁. 歩行率による中等度身体活動時間の評 価. 体力科学, 57 : 453-462, 2008.

18）吉武裕. 高齢者の身体活動量測定システム。厚生省厚 生科学研究補助金長寿科学総合研究, 1997.

19) Tudor-Locke C, Hatano Y, Pangrazi RP, and Kang M. Revisiting "how many steps are enough?". Med Sci Sports Exerc, 40: S537-543, 2008.

20) Swartz AM, Strath SJ, Bassett DR, Moore JB, Redwine
BA, Groër M, and Thompson DL. Increasing daily walking improves glucose tolerance in overweight women. Prev Med, 37: 356-62, 2003.

21) Thompson DL, Rakow J, and Perdue SM. Relationship between accumulated walking and body composition in middle-aged women. Med Sci Sports Exerc, 36: 911-914, 2004.

22）金俊東, 久野譜也, 相馬 りか, 増田 和実, 足立 和隆, 西嶋 尚彦, 石津 政雄, 岡田 守彦. 加齢による下肢 筋量の低下が歩行能力に及ぼす影響. 体力科学, 49 : 589-596, 2000.

23）熊原秀晃, Yves Schutz, 吉岡真由美, 吉武裕, 進藤 宗洋, 田中宏暁. 健康づくりのための運動基準に則し た日常身体活動量評価における歩数の妥当性. 福岡大 学スポーツ科学研究, 39：101-111, 2008.

24) Tudor-Locke C, Craig CL, Brown WJ, Clemes SA, De Cocker K, Giles-Corti B, Hatano Y, Inoue S, Matsudo SM, Mutrie N, Oppert JM, Rowe DA, Schmidt MD, Schofield GM, Spence JC, Teixeira PJ, Tully MA, Blair SN. How Many Steps/day are Enough? For Adults. Int J Behav Nutr Phys Act, 8: 79, 2011. doi:10.1186/14795868-8-79

25) Kumahara H, Schutz Y, Ayabe M, Yoshioka M, Yoshitake $Y$, Shindo M, Ishii K, and Tanaka H. The use of uniaxial accelerometry for the assessment of physical-activity-related energy expenditure: a validation study against whole-body indirect calorimetry. Br J Nutr, 91: 235-243, 2004.

26) Haskell WL, Lee IM, Pate RR, Powell KE, Blair SN, Franklin BA, Macera CA, Heath GW, Thompson PD, and Bauman A. Physical activity and public health: updated recommendation for adults from the American College of Sports Medicine and the American Heart Association. Med Sci Sports Exerc, 39: 14231434, 2007.

27) Macfarlane DJ, Taylor LH, Cuddihy TF. Very short intermittent vs continuous bout of activity in sedentary adults. Prev Med, 43: 332-336, 2006.

28) Miyashita M, Burns SF, Stensel DJ. Accumulating short bouts of brisk walking reduces postprandial plasma triacylglycerol concentrations and resting blood pressure in healthy young men. Am J Clin Nutr, 88: 1225-1231, 2008.

29) Jakicic JM, Wing RR, Butler BA, and Robertson RJ. Prescribing exercise in multiple short bouts versus one continuous bout: effects on adherence, cardiorespiratory fitness, and weight loss in overweight women. Int J Obes Relat Metab Disord, 19: 893-901, 1995. 